\title{
Cellulase Production in the Digestive Organs of Reticulitermes speratus, a Native Termite from Milyang, Korea*1
}

\author{
Young-Min Lee*2, Yoon-Hee Kim*2, Moon-Jung Cho*2, \\ Keum Shin ${ }^{* 2}$, and Yeong-Suk Kim ${ }^{* 2 \dagger}$
}

\begin{abstract}
This study investigated on enzyme production in the digestive organs of the native termite (Reticulitermes speratus) in Milyang, Korea. Four types of major cellulases [EG (endo-1,4- $\beta$-glucanase), BGL ( $\beta$-glucosidase), CBH (cellobiohydrolase) and BXL ( $\beta$-1,4-xylosidase)] were present in the digestive organs of the termite. The strong enzyme activity for BGL was found from the native termite, and also shown that the enzyme was distributed in the salivary gland, foregut, and hindgut. BXL, which breaks down hemicellulose near the amorphous region, was detected mainly from salivary gland, foregut, and midgut. However, CBH was distributed mainly in the hindgut. Meanwhile, EG which degrades cellulose, was found mainly in the hindgut and salivary glands. These facts indicate that celluases production patterns are differ from different sites compare to the same species found in Japan, suggesting that enzyme production in the digestive organs of termites is changed according to their habitats.
\end{abstract}

Keywords : Reticulitermes speratus, Termite, Cellulase, Digestive organs

\section{INTRODUCTION}

Cellulose is one of the most abundant source of renewable biomass on the earth. It consists of long chain molecules, composed of repeating units of two $\beta$-D-glucose residues. It consists of composite forms of highly crystallized microfibrils among amorphous matrices which creates a very complex and recalcitrant physical structure of cellulose found in plant cell walls (Delmer \& Amor, 1995). Lignocellulosic biomass digestion is a complex process, involving a various cellulase with diverse modes of reaction. It has been known that three major enzyme types, EG, $\mathrm{CBH}$ and BGL, were concerned in hydrolysis of cellulose. EG hydrolyzes mainly amorphous cellulose and forms free reducing chain-ends and short-chain oligosaccharides by random cleavage of the $\beta(1 \rightarrow 4)$-bonds of cellulose. $\mathrm{CBH}$ produces mainly cellobiose by endwise hydrolysis of the free reducing end of cellulose or cello-oligosaccharides. BGL hydrolyze cellobiose to glucose.

*1 Received on March 3, 2010; accepted on March 17, 2010

*2 Department of Forest Products and Biotechnology, College of Forest Science, Kookmin University, Seoul 136-702, Korea

† Corresponding author : Yeong-Suk Kim (e-mail: yskim@kookmin.ac.kr) 
Cellulases act each other synergistically to hydrolyze crystalline cellulose to produce glucose (Berghem et al., 1976; Eriksson, 1975; Wood \& McCrae, 1978).

Many cellulolytic systems from a wide array of organisms, including Archaezoa, fungi and bacteria, have been studied. Although the production of a complete cellulolytic system is common among bacteria and fungi, it is unusual among animals, especially insects. Cleveland $(1923,1924)$ proposed that intestinal protozoa were essential for the lower termite, Reticulitermes flavipes, and concentrated on the role of the protozoan fauna in cellulose digestion. Initially, cellulose digestion of the termite was attributed to hindgut bacteria, however the possibility of an endogenous cellulose digesting system was then considered (Breznak \& Brune, 1994; Hogan et al., 1988; O'Brien et al., 1979; Potts \& Hewitt, 1973; Slaytor, 1992). Yamaoka and Nagatani (1975) demonstrated the presence of EG in the salivary glands of Reticulitermes speratus and also showed that the hindgut protozoa of this species had the ability to hydrolyze crystalline cellulose. Slaytor et al. (1997) reported hydrolysis of cellulose in the midgut in the higher termite Nasutitermes walkeri (Hill). The distribution of cellulase in the digestive organs of several species of termites has been reported. Kovoor (1970) showed that most of the EG from Microcerotermes edentatus (Was.) was found in the midgut. On the other hand, it has been reported that the EG and the BGL from Reticulitermes speratus was distributed in the salivary glands and hindgut, respectively (Inoue et al., 1997). Recently, Zhou \& Smith (2007) reported that $64.9 \%$ of EG activity was found in the foregut, whereas $28 \%$ of the activity was present in the hindgut from Reticulitermes flavipes. Also, $61.5 \%$ of $\mathrm{CBH}$ activity was found in the hindgut, whereas $14 \%$ and $12.6 \%$ of the activity was present in the foregut and head, respectively.
Recently, demand for studies on the cellulase for saccharification of the lignocellulosic biomass for bio-alcohol has been increased. However, few studies have been done on the characteristics of digestive enzyme secretion and enzyme activity of cellulases of the native termite of Korea, even though these termites show a vigorous degradability of cellulose. Therefore, this paper reports the results of an investigation of the enzyme producing site and activity of cellulases from a termite from Milyang, Korea. In particular, we report the distribution of cellulases in the digestive organs of the native termite in Korea.

\section{MATERIALS and METHODS}

\subsection{Termites and Their Identification}

Tested termites were collected in Milyang-si, Kyungsangnamdo, Korea and were identified as Reticulitermes speratus, based on the termite taxonomy we observed with an image analyzer (BVS-314, SomeTech). Adult workers and soldiers of the tested termite, which is the same species as Park and Bae's identification, is shown in Fig.1(a) and Fig.1(b) (Park \& Bae, 1997). Test termites were cultured in dark conditions at $26^{\circ} \mathrm{C}$ with $65 \%$ relative humidity with pine wood blocks as food. Adult workers were used for all experiments.

\subsection{Preparation of Enzyme Extracts from Termites}

Twenty healthy adult workers were used for experiments. The digestive organs of each termite were removed with forceps as shown in Fig. 2 3, and divided into salivary glands, midgut and hindgut. Each section was mixed with $400 \mu$ of $0.1 \mathrm{M}$ sodium acetate buffer (SAB) (pH 5.5) and phenyl-methyl sulfonyl fluoride (PMSF), then ultrasonicated with a sonic 

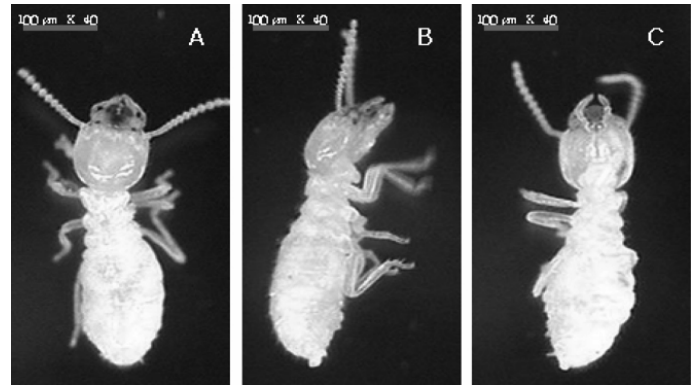

Fig. 1(a). Worker of tested termite (Reticulitermes speratus).
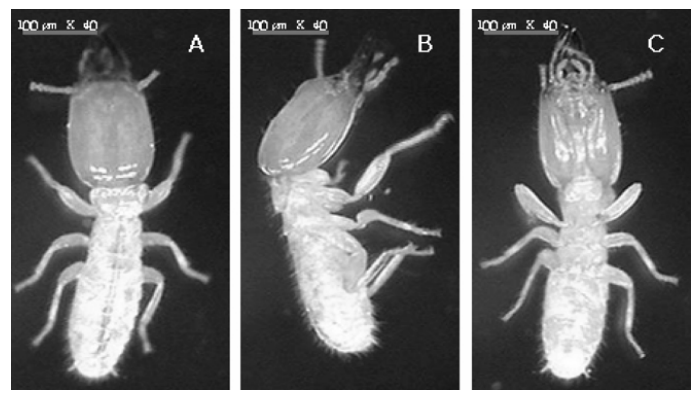

Fig. 1(b). Soldier of tested termite (Reticulitermes speratus).

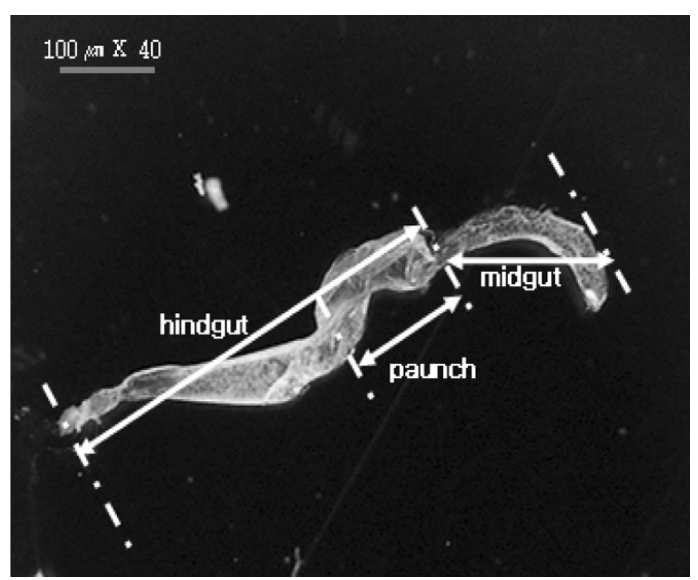

Fig. 2. Digestive organs of the tested termite.

dismembrator. Homogenates were centrifuged at $13,000 \mathrm{rpm}$ for $25 \mathrm{~min}$. The supernatant from each section was used to measure activity of

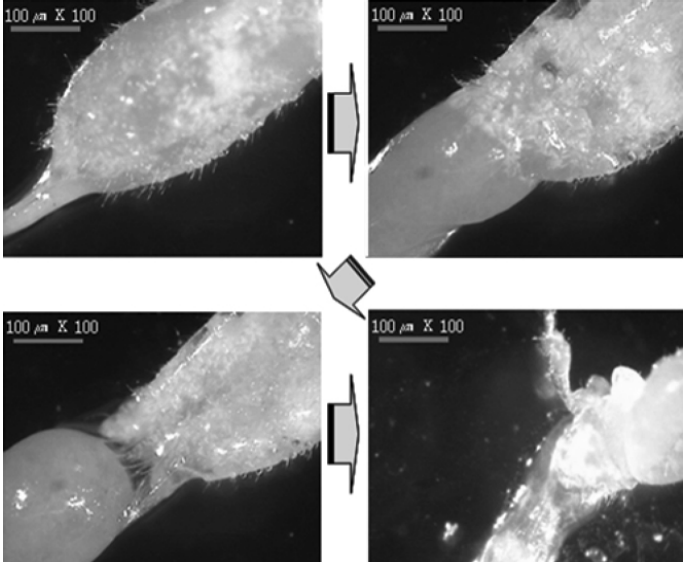

Fig. 3. Extraction of the gut from of tested termite.

cellulases and on PAGE gels. All operations were carried out at $4^{\circ} \mathrm{C}$.

\subsection{Enzyme Assays and Protein Mea- surement}

EG activity was assayed in $50 \mu$ reaction mixtures containing 2\% (w/v) carboxymethylcellulose (Sigma-Aldrich Fine Chemicals, Co.) in $100 \mathrm{mM}$ sodium acetate buffer $(\mathrm{pH} \mathrm{5.5)}$ at $50^{\circ} \mathrm{C}$. Reducing sugars were determined by the Somogyi-Nelson method (Nelson, 1944). One unit (U) of activity was defined as the amount of enzyme releasing $1 \mathrm{nmol}$ of reducing sugar per hour. BGL activity was assayed using $p$-nitrophenyl- $\alpha$-D-galactopyranoside ( $p$-NPG, SigmaAldrich) as substrate. The $1 \mathrm{~m} \ell$ enzymatic reaction mixtures containing $100 \mu l$ of the test solution and $10 \mathrm{mM} p-\mathrm{NPG}$ in $1 \mathrm{M}$ sodium acetate buffer $(\mathrm{pH} 5.5)$ were incubated for 15 $\min$ at $50^{\circ} \mathrm{C}$. The amount of $p$-nitrophenol released was determined by the increase in absorbance at $\mathrm{A}_{405}$ in UV/VIS spectroscopy after the addition of $\mathrm{Na}_{2} \mathrm{CO}_{3}$ to the reaction mixture. One unit of $p$-NPG hydrolyzing activity was defined as the amount of enzyme releasing $1 \mathrm{nmol}$ of p-nitrophenol per hour. CBH and BXL activ- 
Young-Min Lee, Yoon-Hee Kim, Moon-Jung Cho, Keum Shin, and Yeong-Suk Kim

Table 1. Distribution of cellulases in digestive organs of the test termite (Reticulitermes speratus)

\begin{tabular}{|c|c|c|c|c|c|}
\hline \multirow{2}{*}{\multicolumn{2}{|c|}{ Enzyme activity }} & \multicolumn{4}{|c|}{ Organ } \\
\hline & & Salivary gland & Midgut & Hindgut & Whole \\
\hline \multirow{3}{*}{$\begin{array}{l}\text { Endo- } \beta-1,4- \\
\text { glucanase }\end{array}$} & Activity (U/termite) & 2.5 & 0.9 & 3.5 & 7.6 \\
\hline & $(\%)$ & $(33.1)$ & $(11.7)$ & $(46.1)$ & (100) \\
\hline & 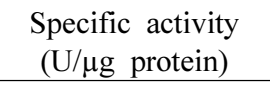 & 15 & 14.8 & 21.2 & 22.8 \\
\hline \multirow[b]{2}{*}{ Cellobio-hydrolase } & $\begin{array}{c}\text { Activity (U/termite) } \\
(\%)\end{array}$ & $\begin{array}{l}14.9 \\
(6.9)\end{array}$ & $\begin{array}{c}11 \\
(5.1)\end{array}$ & $\begin{array}{l}118.4 \\
(54.4)\end{array}$ & $\begin{array}{l}217.6 \\
(100)\end{array}$ \\
\hline & 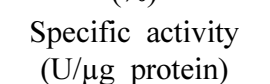 & 22.3 & 45.9 & 179.5 & 161.2 \\
\hline \multirow{2}{*}{$\beta$-glucosidase } & $\begin{array}{c}\text { Activity (U/termite) } \\
(\%)\end{array}$ & $\begin{array}{l}1530.2 \\
(22.5)\end{array}$ & $\begin{array}{l}783.7 \\
(11.5)\end{array}$ & $\begin{array}{c}2199.9 \\
(32.3)\end{array}$ & $\begin{array}{c}6812.4 \\
(100)\end{array}$ \\
\hline & 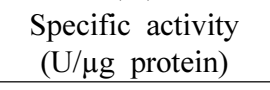 & 2283.9 & 3265.2 & 3333.1 & 5046.2 \\
\hline \multirow{2}{*}{$\beta$-1,4-xylosidase } & $\begin{array}{c}\text { Activity (U/termite) } \\
(\%)\end{array}$ & $\begin{array}{l}217.2 \\
(22.9)\end{array}$ & $\begin{array}{l}381.1 \\
(40.2)\end{array}$ & $\begin{array}{c}100 \\
(10.5)\end{array}$ & $\begin{array}{l}948.1 \\
(100)\end{array}$ \\
\hline & 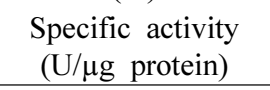 & 324.2 & 1588.1 & 151.5 & 702.3 \\
\hline
\end{tabular}

ities were assayed using $p$-NPL and $p$-NPX (Sigma-Aldrich) as substrate. The methods for the determination of $\mathrm{CBH}$ and BXL activities were the same as the BGL assay, but incubation time was $30 \mathrm{~min}$. The protein concentration in the enzyme solution was measured by the method of Bradford (Bradford, 1976).

\subsection{Electrophoresis}

Crude extracts were examined by sodium dodecyl sulfatepolyacrylamide gel electro-phoresis (SDS-PAGE) according to the method described by Laemmli (Laemmli, 1970). The slab gel consisted of $10 \%(\mathrm{w} / \mathrm{v})$ resolving gel, $12 \%(\mathrm{w} / \mathrm{v})$ resolving gel and 5\% (w/v) stacking gel. Proteins and standard mixture (Precision Plus Protein Standards, Bio-Rad) were stained using Coomassie Brilliant Blue R250 (Sigma).

\section{RESULTS and DISCUSSION}

\subsection{Activities and Distribution of Cellu- lase from Termites}

Results of activities and distribution of cellulase in the digestive system of Reticulitermes speratus was shown in Table 1 and Fig. 4. The specific activity of the enzyme from whole body of a test termite was $5,046(\mathrm{U} / \mu \mathrm{g}$, protein)

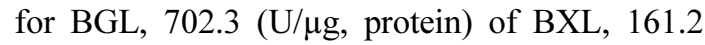

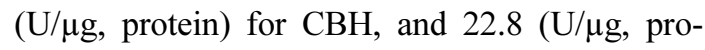
tein) for EG (Table 1), especially, showing the very high activity for BGL. These results are different from those obtained from Azuma and Koshijima's report (1984) from which carboxymethyl cellulase and xylosidase were the highest activity of enzyme from termite. In this study, EG was distributed in the hindgut (46\%) and salivary glands (33\%). BGL was almost equally distributed in the foregut, hindgut and salivary gland. $\mathrm{CBH}$, which mainly breaks down the crystalline regions of cellulose, was 

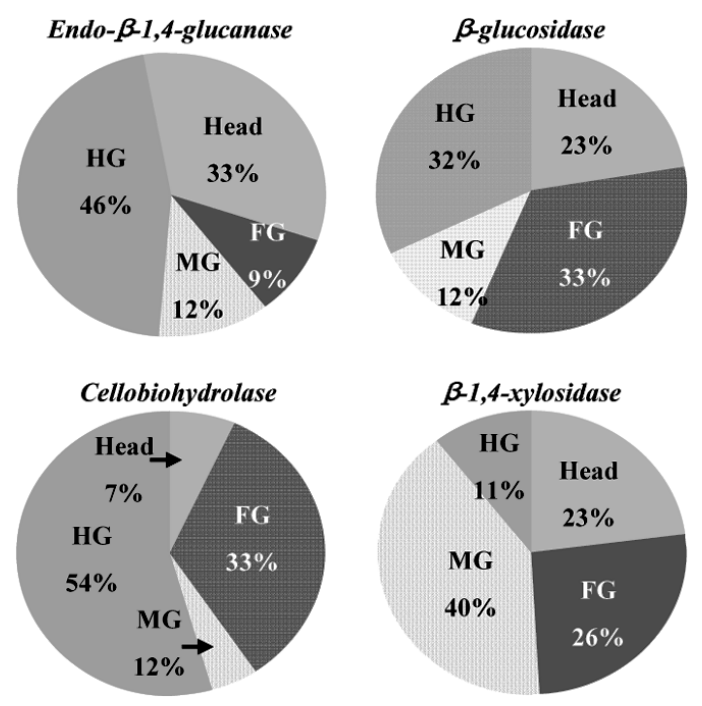

Fig. 4. Distribution ratio of cellulases in digestive organs of the test termite (Reticulitermes speratus).

found in hindgut (54\%), and $40.2 \%$ of BXL, which, on the other hand, mainly breaks down the hemicellulose near the amorphous region, was found rather in the midgut than in the hindgut.

The enzyme distribution pattern of the test termites was different from the same species in Japan. Inoue et al. (1997) reported that, in Reticulitermes speratus, $77.8 \%$ of EG activity was found in the salivary glands and $74.2 \%$ of BXL activity was found in the hindgut. Also, in several termite species, such as Nasutitermes takasagoensis, Microcerotermes edentatus (Was.), Trinervitermes trinervoides (Masutitermitinae), Macrotermes subhyalinum, Coptotermes formosanus, and Odontotermes formosanus, EG or BGL was high in the midgut (Potts \& Hewitt, 1973; Kovoor, 1970; Tokuda et al., 1997, Veivers et al., 1991; Mo et al., 2004).

In view of the current results and references, enzyme distribution in the digestive organs may differ according to the species or habitat of the same species. The distribution of cellulase among

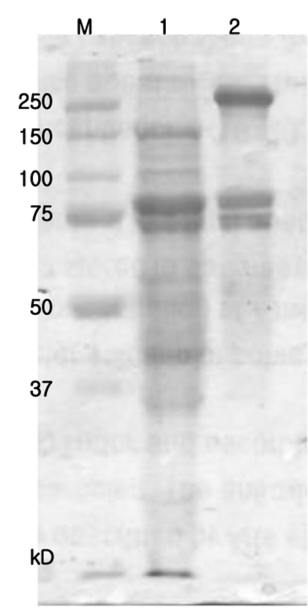

Fig. 5. 10\% SDS-PAGE of enzyme from the digestive organs from Reticulitermes speratus. M : Marker, 1 : Whole body, 2 : Salivary gland.

termites is closely linked to their postnatal habitat, as well as their phylogenetic relationships. And the results imply that cellulose and hemicellulose in amorphous region may be hydrolyzed by EG, BXL, and BGL in the salivary gland, foregut or midgut, followed by cellulose hydrolysis in crystalline region by $\mathrm{CBH}, \mathrm{EG}$, and BGL in the midgut and hindgut.

\subsection{Enzyme Pattern of the Cellulase from the Tested Termite}

Electrophortic patterns of crude enzyme extract from each digestive organ are shown Fig. 5 and Fig. 6. Characteristic proteins are appeared at $150 \mathrm{kDa}, 108 \mathrm{kDa}, 77 \sim 78 \mathrm{kDa}, 72 \sim$ $73 \mathrm{kDa}, 60 \mathrm{kDa}, 52 \mathrm{kDa}, 41 \sim 42 \mathrm{kDa}$, and 35 $\mathrm{kDa}$ in the whole body extract. Based on our current experiments the band at $78 \mathrm{kDa}, 108$ $\mathrm{kDa}$ seem to correspond to BGL from Trichoderma reesei and $\mathrm{CBH}$ from Paenibacillus polymyxa $(108.5 \mathrm{kDa})$, respectively. Furthermore the $60 \mathrm{kDa}, 52 \mathrm{kDa}$, and $41 \sim 42 \mathrm{kDa}$ proteins were similar to the BGL from Neotermes koshunensis (Shiraki) $(60 \mathrm{kDa})$, the $\mathrm{EG}$ from Macrotermes 
Young-Min Lee, Yoon-Hee Kim, Moon-Jung Cho, Keum Shin, and Yeong-Suk Kim

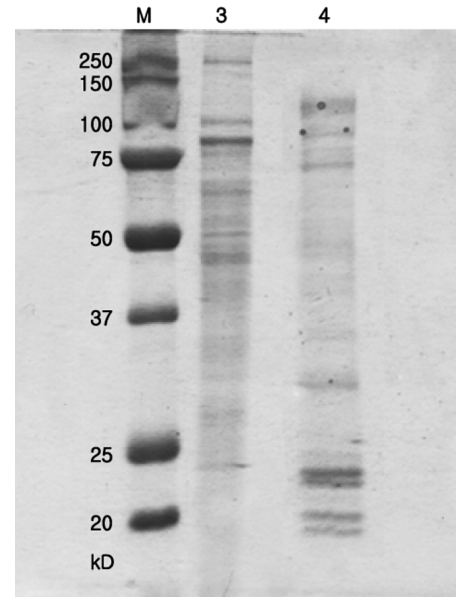

Fig. 6. 12\% SDS-PAGE of proteins from the digestive organs from Reticulitermes speratus. M : Marker, 3 : Hindgut, 4 : Midgut.

(52 kDa) and the EG from Reticulitermes speratus (41, $42 \mathrm{kDa})$ (Veivers et al., 1991; Tokuda et al., 2002; Watanabe et al., 1997; Nakashima \& Azuma, 2000). Also, the $23 \mathrm{kDa}$ and $24 \mathrm{kDa}$ bands expressed in the midgut were similar to the BXL from Trichoderma harzianum $(23 \mathrm{kDa})$ and Bacillus substilus $(23.4 \mathrm{kDa})$. The $87 \mathrm{kDa}$ band was similar to BXL from Trichoderma reesei (87.2 kDa) (Ncbi, 2008).

In summary, by the comparison of protein bands of crude extract of the termite, with those of already identified from other microorganisms, the termite seems to have major enzymes to digest cellulosic materials in their gut, although to further purification and identification for each protein are needed.

\section{CONCLUSION}

This study was investigated on digestive enzyme production in the digestive organs of the native termite in Milyang, Korea. Test termites were collected and identified as Reticulitermes speratus with adult workers and soldiers. Pro- ducing sites of digestive enzyme were identified with isolation of digestive organs from workers of tested termites and the enzyme activities of each cellulase were analyzed. From the measurement of their activity showed four types of major enzymes (EG, BGL, CBH and BXL) were found in the digestive organs of the termite (Reticulitermes speratus). And it was shown the strong enzyme activity for BGL in test termite, and BGL was distributed mainly in the salivary gland, foregut and hindgut. BXL which breaks down hemicellulose near the amorphous region, was detected mainly in salivary gland, foregut and midgut. However, $\mathrm{CBH}$ was distributed mainly in the hindgut. EG which degrades cellulose, was found mainly in the hindgut and salivary glands. These results showed a different producing site pattern in cellulase compared to the same species found in Japan, suggesting enzyme production in the digestive organs might differ according to the habitat differences of the same species.

\section{Acknoledgement}

This study was carried out with the support of Forest Science and Technology Project (S210707L010110) provided by Korea Forest Service.

\section{REFERENCES}

1. Delmer D. P, and Y. Amor. 1995. Cellulose Biosynthesis. Plant Cell. 7: 987 1000.

2. Berghem, L. E. R., L. G. Pettersson, and U.-B. Axio-Fredriksson. 1976. Eur J. Biochem. 61: 621 $\sim 630$.

3. Eriksson, K.-E. 1975. in Symposium on Enzymatic Hydrolysis of Cellulose, Finnish National Fund for Research and Development, pp. 263 280, Helsinki.

4. Wood, T. M. \& S. and McCrae. 1978. Adv. Chem. Ser. 181: $181 \sim 120$. 
Cellulase Production in the Digestive Organs of Reticulitermes speratus, a Native Termite from Milyang, Korea

5. Cleveland, L. R. 1923. Symbiosis Between Termites and Their Intestinal Protozoa. Proc. Natl. Acad. Sci. USA., 9: 424 428 .

6. Cleveland, L. R. 1924. The physiological and symbiotic relation ship between the intestinal protozoa of termites and their host with special reference to Reticulitermes flavipes Kollar. Biol. Bull.46: $178 \sim 227$.

7. Breznak, J. A. \& Brune, A. 1994. Role of microorganisms in the digestion of lignocellulose by termites. Annu. Rev. Entomol. 39: 453 487.

8. Hogan, M., P. C. Veivers, M. Slaytor, R. T. Czolij. 1988a. The site of Cellulose Breakdown in Higher Termites (Nasutitermes walkeri and Nasutitermes exitiosus). J. Insect Physiol. 34: 891 $\sim 899$.

9. O’Brien, G. W., P. C. Veivers, S. E. McEwen, M. Slaytor, and R. W. O'Brien. 1979. The Origin and Distribution of Cellulase in the Termites, Nasutitermes exitiosus and Coptotermes lacteus. Insect Biochem. 9: 619 625.

10. Potts, R. C. and P. H. Hewitt. 1973. The distribution of intestinal bacteria and cellulase activity in the harvester termite, Trinervitermes trinervoides (Nasutitermitinae). Insects Soc. 20: 215 $\sim 220$.

11. Slaytor, M. 1992. Cellulose Digestion in Termites and Cockroaches: What role do Symbionts Play? Comp. Biochem. Physiol. 103B: 775 784 .

12. Yamaoka I. and Y. Nagatani. 1975. Cellulose digestion system in the termite, Reticulitermes speratus (Kolbe). I. Producing sites and physiological significance of two kinds of cellulase in the worker. Zool. Mag. 84: 23 29 .

13. Slaytor, M., P. C. Veivers, and N. Lo. 1997. Aerobic and Anaerobic Metabolism in the Higher Termite Nasutitermes walkeri (Hill). Insect Biochem. Mol. Biol. 27: 291 303 .

14. Kovoor, J. 1970. Presence d'enzyme cellulolytiques dans l'intestin d'um termite superieur Microcerotermes edentatus (Was.). Ann. Sci. Nat. Zool. 12: $65 \sim 71$.

15. Inoue, T., K. Murashima, J.-I. Azuma, A. Sugimoto and M. Slaytor. 1997. Cellulose and xylan utilization in the lower termite Reticulitermes speratus. J. Insect Physiol. 43: 235 242.

16. Zhou, X.G. and A. J. Smith. 2007. Correlation of cellulase gene expression and cellulolytic activity throughout the gut of the termite Reticulitermes flavipes. Elsevier. Gene 395: 29 39.

17. Park, H. C. and T. W. Bae. 1997. Morphological description of Reticulitermes speratus kyushuenesis Morimoto (Isoptera : Rhinotermitidae) in Southern part of Korea, Korean J. Soil Zoology 2(1): $59 \sim 64$

18. Nelson, N. 1944. A photomeric adaption of the Somogyi method for the determination of glucose. J. Biol. Chem. 153: 375 380 .

19. Bradford M. M. 1976. A rapid and sensitive method for the quantitation of microgram quantities of protein utilizing the principle of protein-dye binding. Anal. Biochem. 72: 248 254.

20. Laemmli, U. K. 1970. Cleavage of structural proteins during the assembly of the head of bacteriophage T4. Nature. 227: 680 685.

21. Azuma J. I. and T. Koshijima. 1984a. Enzymatic Saccharification of Wood Plants. Wood Research. 70: $17 \sim 24$.

22. Tokuda, G., H. Watanabe, T. Matsumoto, and H. Noda. 1997. Cellulose digestion in the wood-eating higher termite, Nasutitermes takasagoensis (Shiraki): distribution of cellulose and properties of Endo-glucanase, G. Zool. Sci. 14: 83 93.

23. Veivers, P. C., R. Muhlemann, M. Slaytor, R. H. Leuthold and D. E. Bignell. 1991. Digestion, diet and polytheism in two fungus-growing termites: Macrotermes subhyalinum Rambur and M. michaelseni Sjostedt. J. Insect Physiol. 37: $675 \sim 682$.

24. Mo, J. C., T. Yang, X. G. Song and J. A. Cheng. 2004. Cellulase activity in five species of important termites in China. Appl. Entomol. Zool. 39(4): $635 \sim 641$.

25. Tokuda, G., H. Saito, and H. Watanabe. 2002. A digestive B-GLucosidase from the salivary glands of the termite, Neotermes koshunensis (Shiraki) : distribution, characterization and isolation of its precursor cDNA by 5'- and 3'- RACE amplifications with degenerate primers. Insect Biochem. and Molecul. Biol. 32: 1681 1689.

26. Watanabe, H., M. Nakamura, G. Tokuda, I. Yamaoka, A. M. Scrivener, and H. Noda. 1997. Site of Secretion and Properties of Endogenous EG Components from R.S. (Kolbe), a Japanese 
Young-Min Lee, Yoon-Hee Kim, Moon-Jung Cho, Keum Shin, and Yeong-Suk Kim

Subterranean Termite. Insect Biochem. Molec. Biol. 27: 305 313.

27. Nakashima, K. and J. Azuma. 2000. Distribution and Properties of Endo-Glucanase from a Lower
Termite, Coptotermes formosanus (Shiraki). Biosci. Biotechnol. Biochem. 64(7): 1500 1506.

28. http://www.ncbi.nlm.nih.gov/ 